\title{
RECORD OF OCELLATED SHRIMP GOBY, TOMIYAMICHTHYS RUSSUS (ACTINOPTERYGII: PERCIFORMES: GOBIIDAE), FROM THE ANDAMAN ISLANDS, INDIA
}

\author{
Jayasimhan PRAVEENRAJ ${ }^{1 *}$, Ponnakulam Thomas RAJAN², Rajendran KIRUBA-SANKAR ${ }^{1}$, \\ and Sibnarayan DAM ROY ${ }^{1}$ \\ ${ }^{1}$ Central Island Agricultural Research Institute, Indian Council of Agricultural Research, Port Blair, Andaman and \\ Nicobar Islands, India \\ ${ }^{2}$ Andaman and Nicobar Regional Centre, Zoological Survey of India, Port Blair, Andaman and Nicobar Islands, \\ India
}

Praveenraj J., Rajan P.T., Kiruba-Sankar R., Dam Roy S. 2017. Record of ocellated shrimp goby, Tomiyamichthys russus (Actinopterygii: Perciformes: Gobiidae), from the Andaman Islands, India. Acta Ichthyol. Piscat. 47 (4): 407-410.

\begin{abstract}
The ocellated shrimp goby, Tomiyamichthys russus (Cantor, 1849), is reported for the first time from the Andaman Islands, India based on a single, female specimen collected during a shore seine operation at Port Blair, South Andaman. The examined specimen is described taking into account the meristics, morphometry, sensory pore arrangement, and the papillae pattern. This finding constitutes the first report of the genus Tomiyamichthys from the Andaman Sea, with a range extension towards Andaman coast.
\end{abstract}

Keywords: Island, Archipelago, marine goby, marine fish, range extension, morphology

There are 14 valid shrimp goby species representing the genus Tomiyamichthys Smith, 1956 (see Hoese et al. 2016). The common name of those fishes indicates their association with shrimps (Decapoda: Alpheidae). The fish and the shrimp are known to share their burrows (Allen and Erdmann 2012, Hoese et al. 2016). Fishes representing the genus Tomiyamichthys are distributed from the Red Sea through the Indian Ocean to the western Pacific Ocean. All known species of this genus have been described based on a single specimen or very few specimens, predominantly females (Hoese et al. 2016). Until recently, 131 species of gobies, belonging to 55 genera, were reported from the Andaman and Nicobar Islands (ANI) by Rajan and Vikas (2015). The above-mentioned authors listed 15 species of shrimp gobies, representing five genera, namely, Amblyeleotris, Cryptocentrus, Ctenogobiops, Mahidolia, and Vanderhorstia. The present paper provides the first record of a fish representing the genus Tomiyamichthys, previously unrecorded in the Andaman Islands.

On 7 March 2017, a female goby specimen measuring $59.27 \mathrm{~mm}$ standard length (SL) was collected using a beach seine operating at $2 \mathrm{~m}$ depth at Corbyn's Cove $\left(11^{\circ} 38^{\prime} 40.60^{\prime \prime} \mathrm{N}, 92^{\circ} 44^{\prime} 52.97^{\prime \prime} \mathrm{E}\right)$ (Fig. 1.) located at Port Blair, South Andaman. The bottom profile of the cove was sandy, and no information was available about a possible association of the presently described specimen with alpheid shrimp. The identification to the genus level was carried out based on morphometry and comparison with the descriptions given by Shibukawa et al. (2005) and Hoese et al. (2016). Pores and sensory papillae nomenclature followed Akihito et al. (1984) and Miller (1986). The examined material was deposited in the marine fish section of the Museum at the Central Island Agricultural Research Institute (catalogue number: CIARI/MF-01). The specimen was assigned to the genus Tomiyamichthys based on the presence of truncate mental fraenum; the presence of membrane covering the gill slit about ventral one-third or in the lower part; a longitudinal pattern of sensory-papillae rows on cheek; uniserial transverse sensory-papillae row just behind the lower-jaw symphysis; scales ctenoid posteriorly. Subsequently, the specimen was identified as Tomiyamichthys russus (Cantor, 1849) (Fig. 2.), based on the following characters: second dorsal and anal fin with one spine and 10 rays; pectoral fin rays 17; lateral scales 77 ; transverse scales 26 , which matches well with the description given by Shibukawa et al. (2005) and Hoese et al. (2016). Though, T. russus appears to be closely related to its congener Tomiyamichthys levisquama Hoese, Shibukawa et Johnson, 2016 from Queensland, Australia, it can be distinguished from the latter in possessing: ctenoid scales posteriorly versus cycloid scales; $74-95$ versus $50-70$ lateral scales; lack of dark medial bar on the pelvic fin versus presence; orange spots on the head versus elongate bars. 


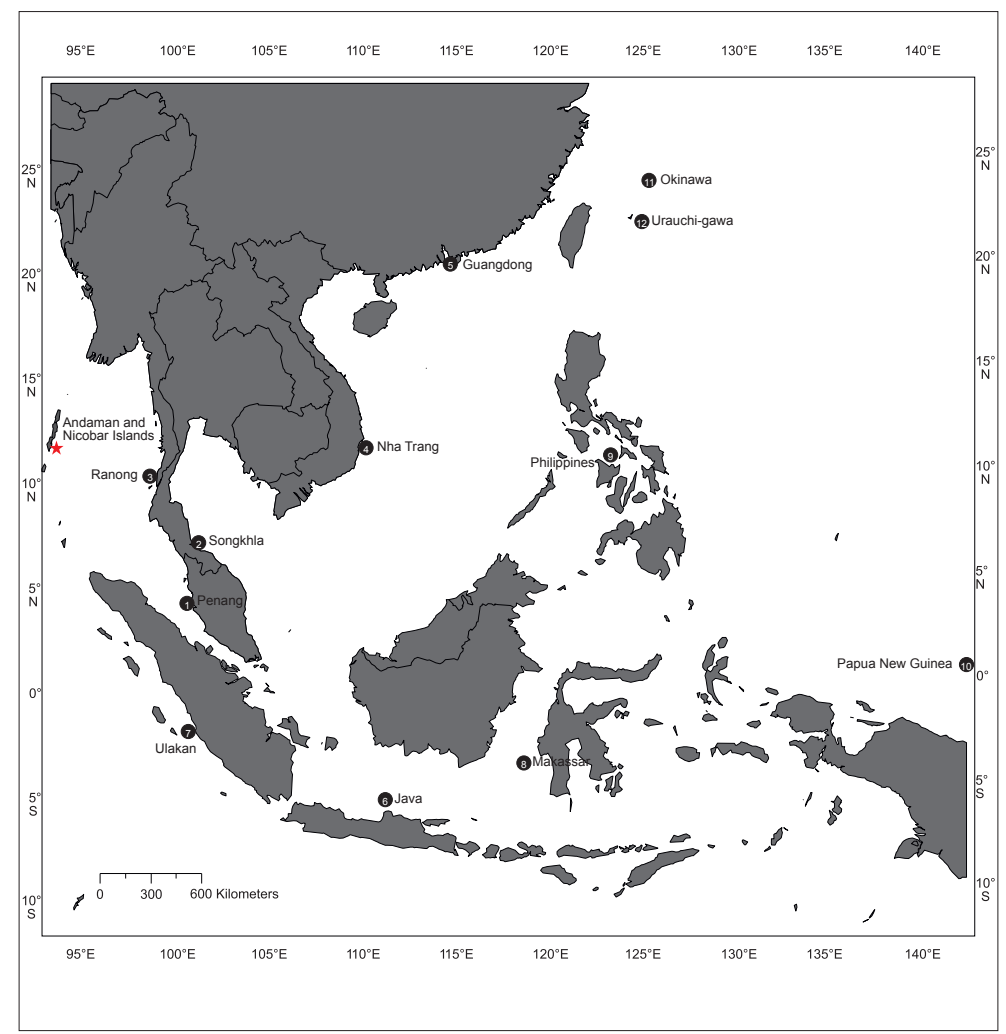

Fig. 1. Distribution of Tomiyamichthys russus in eastern Indian and western Pacific; previous records $1-12,(1=$ Penang, $2=$ Songkhla, $3=$ Ranong, $4=$ Nha Trang, $5=$ Guangdong, $6=$ Java, $7=$ Ulakan, $8=$ Makassar, $9=$ Philippines, $10=$ Papa New Guinea, 11 = Okinawa, 12 = Urauchi-gawa), $\wedge$ presently reported record from Andaman Islands

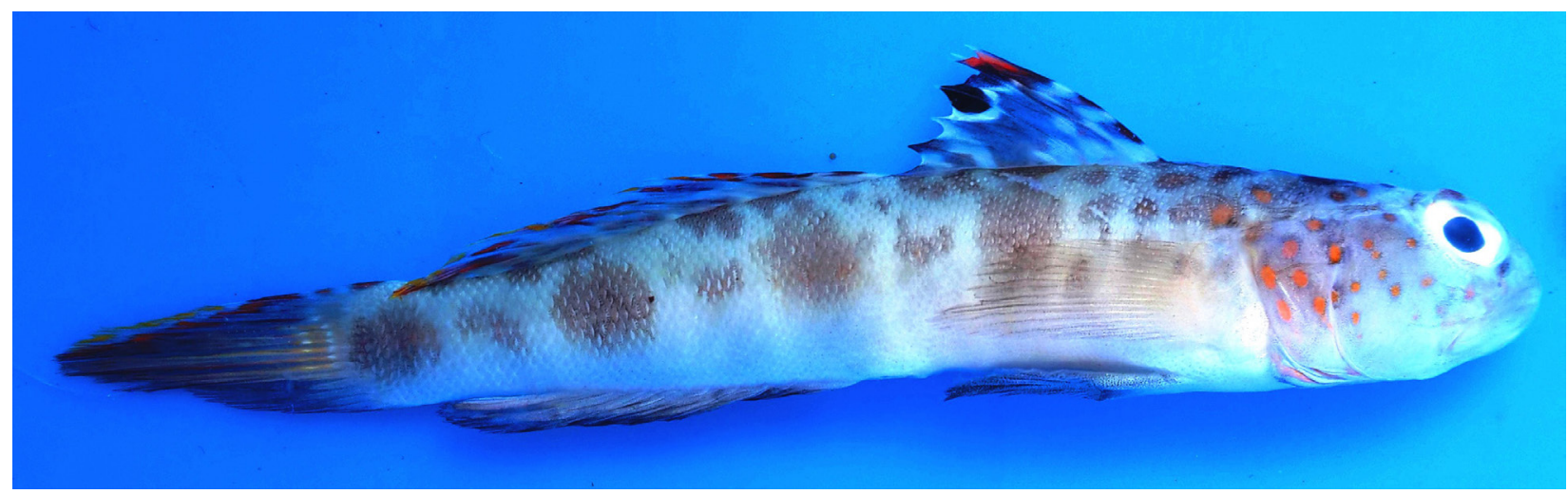

Fig. 2. Tomiyamichthys russus (CIARI/MF-01) from the Corbyn's Cove, Andaman Islands

Description of the Andaman specimen. For morphometry see Table 1. Meristics are as follows: dorsal spines six, second dorsal fin and anal fin with one spine, 10 branched rays and an additional ray attached to the base of the 10th branched ray; pelvic fin with one spine, 5 branched rays; pectoral fin with 17 branched rays; segmented caudal-fin rays $9+8$ including $7+6$ branched rays; lateral scales 77; transverse scales from the first dorsal fin origin running transversely downward towards the abdomen 32; transverse scales from the second dorsal fin origin to the anal fin origin 26; predorsal scales 5; scales from the mid line of the pectoral fin, running horizontally below the second dorsal fin are cycloid, that is $1-40,41$ st to 77th scales are ctenoid; cheek naked; premaxilla with six inwardly curved conical teeth in the outer row and smaller teeth in the inner row; dentary with four rows of teeth and 12 large conical teeth in the outer row, of which one tooth in lateral side is visible upon closure of the jaw.

The anterior oculoscapular canal begins with pores B, C, and D (unpaired), and E, F, and H (pore G could not be located) (paired). The pore $\mathrm{B}$ is found opposite to the posterior nostril (PN). The anterior nostril (AN) is located below the posterior nostril, close to the upper jaw lip. A series of uniserial transverse rows of papillae, (a, b, c, $\mathrm{cp}, \mathrm{d}, \mathrm{e}, \mathrm{i}$ ) in the cheek is present (Fig. 3A). Presence of five papillae originating in the predorsal, in continuation 
with the pore D and E, diminishing exactly opposite to the operculum, and further continuing with a series of six papillae ending in dorsal fin origin (Fig. 3B).

Coloration. Body pale grey with a series of large irregular black blotches mid laterally on the body, continuous with similar colour saddle-like blotches crossing dorsum. Transverse rows of small orange spots bordered by dull black circles in the cheek, preopercle, and operculum, which runs over the head and predorsal area; posterior part of gill membrane orange; operculum with pale violet tinges. The colour of dorsal spine membrane pale grey with continuous saddle-like dark grey blotches at the midbase, a prominent black spot, with narrow white ventral margin in the distal part of dorsal spine membrane located between third and fifth spines and partially spreading in the second and third spine membrane. Distal margin of the dorsal fin orange; second dorsal fin greyish white, distal half with rows of orange spots, extreme distal end of the dorsal fin yellow bordered by violet. Anal fin light grey, with pale orange distal margins; pectoral fin transparent; pelvic fin greyish-black. Caudal fin greyishblack with orange mid-anterior area surrounded by white margin, followed by yellow bands radiating from the caudal peduncle; posterodorsal part of caudal fin with yellow margin and reddish-orange submargins outlined by narrow violet. Coloration in alcohol: body greyish olive; Pelvic fin black; dorsal spine membrane grey with inconspicuous black botches; cheek with five transverse dull brown spots.
Table 1

Morphometric characters of Tomiyamichthys russus (CIARI/MF-01) from the Corbyn's Cove, Andaman Islands

\begin{tabular}{lrr}
\hline \multicolumn{1}{c}{ Morphometric character } & AV & \%SL \\
\hline SL & 59.27 & \\
Head length & 28.4 \\
Snout length & 4.4 \\
Eye diameter & 8.6 \\
Inter orbital width & 2.1 \\
Nape width & 10.6 \\
Head width & 14.0 \\
Head depth & 16.6 \\
Jaw length & 11.5 \\
Body width & 10.9 \\
Body depth & 16.4 \\
Predorsal length & 33.0 \\
Prepelvic length & 31.5 \\
Preanal length & 61.1 \\
Caudal peduncle length & 18.7 \\
Caudal peduncle depth & 9.6 \\
First dorsal fin base length & 20.4 \\
Second dorsal fin base length & 30.3 \\
Anal fin base length & 24.8 \\
Pelvic fin length & 17.0 \\
Caudal fin length & 25.4 \\
Pectoral fin length & 18.5 \\
\hline
\end{tabular}

$\mathrm{AV}=$ absolute value $[\mathrm{mm}], \% \mathrm{SL}=$ relative value $[\%$ of standard length $]$.

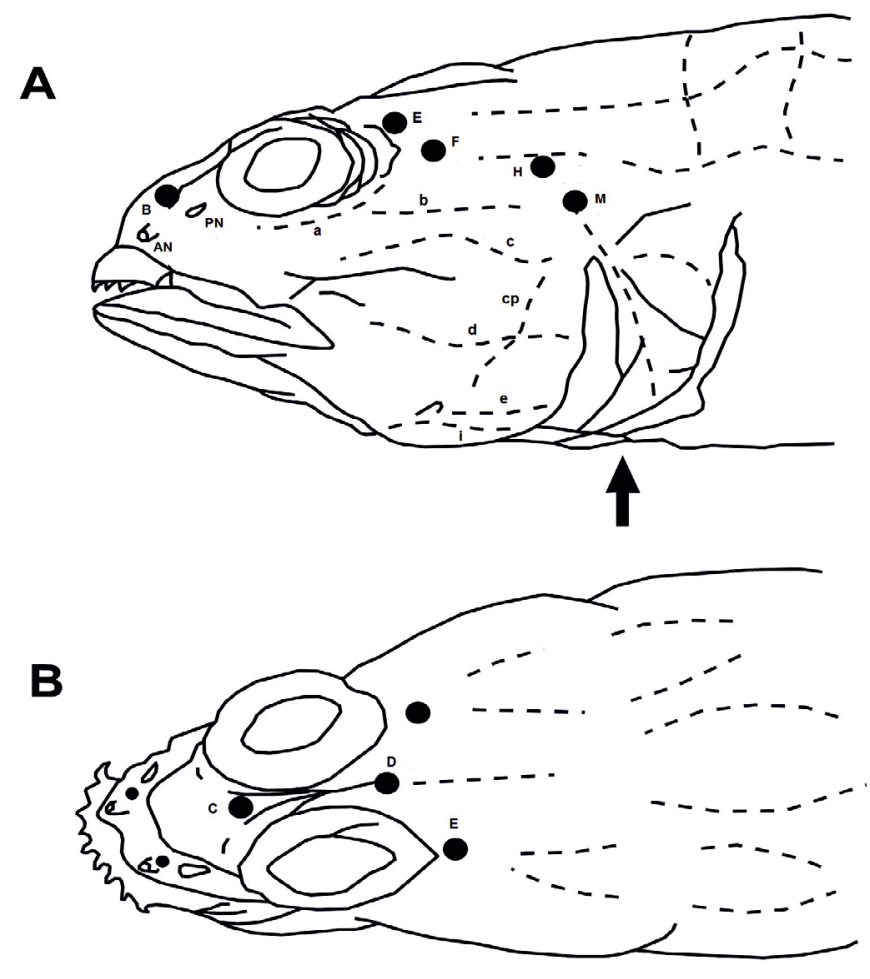

Fig. 3. Diagram of Tomiyamichthys russus (CIARI/MF-01) showing pores and papillae. A. Lateral view (arrow showing gill membrane), B. Dorsal view (Drawn by J. Praveenraj) 
Remarks. Tomiyamichthys russus was described by Cantor (1849: 1168-1169) as Gobius russus from Penang, Malaysia. Shibukawa et al. (2005) noted that this species has been recorded under various names such as 'Cryptocentrus polyophthalmus' in Kuiter and Tonozuka (2001) and 'Flabelligobius sp. 2' in Senou et al. (2004). They redescribed the fish from fresh materials, and indicated that the characters fit under the genus Flabelligobius Smith, 1956. Hoese et al. (2016) verified Flabelligobius as the junior synonym of Tomiyamichthys, by stating that the type species of both the genera contain the same features. The genus was separated from other Indo-Pacific shrimp gobies, in possessing partial closure of the gill slit by a membrane; having an equal number of dorsal and anal rays; gill rakers on the first gill arch rudimentary or short, 11 or fewer in total number; welldeveloped longitudinal pattern of sensory-papillae rows on cheek and a uniserial transverse row of sensory papillae just behind the chin (Shibukawa et al. 2005). Presently, the distribution of the T. russus is known from western Pacific and eastern Indian Ocean (Shibukawa et al. 2005, Hoese et al. 2016). The nearest recorded site for T. russus from Corbyn's Cove is Ranong, Thailand. Both regions are on the same sea (Andaman Sea). The record from Papua New Guinea is the southern western record in the Pacific Ocean, and the easternmost record is from the Okinawa Islands. A considerable variation in the lateral scale count, preopercular pores and coloration are noted in T. russus examined by Shibukawa et al. 2005 and Hoese et al. 2016. Similarly, in the Andaman specimen, the anterior oculoscapular pore $(\mathrm{G})$ and preopercular canal pore $(\mathrm{N}, \mathrm{O})$ could not be located. On the contrary, presence and absence of $\mathrm{N}$ pore were noted in the specimens from Thailand and Vietnam (Shibukawa et al. 2005). However, the pectoral fin, caudal fin, transverse scales (first dorsal fin base to the anal fin) count in Andaman specimen matches well with Japanese one (OMNH-P 18055), syntype (BMNH 1860.3.19.5731), Vietnam and Thailand specimens examined in Shibukawa et al. (2005). To understand their population distribution and intraspecific variations, a comprehensive study involving DNA barcoding methodology might impart additional information.

\section{ACKNOWLEDGEMENTS}

The authors acknowledge the externally funded project on "Consortia research platform on Agrobiodiversity", New Delhi for the grants. The first and the second authors are grateful to Dr John Randall, Bishop Museum, and Dr Helen Larson, Australian Museum for their constructive comments and literature support. The first author wholeheartedly thanks Balakrishna, Krishnan Kannan, M.P. Goutham Bharati, and Deepak Ganguly for the preparation of line diagram and vector graphics.

\section{REFERENCE}

Akihito Prince, Hayashi M., Yoshino T. 1984. Suborder Gobioidei. Pp. 236-238. In: Masuda H., Amaoka K., Araga C., Uyeno T., Yoshino T. (eds.) Fishes of the Japanese Archipelago. Tokai University Press, Tokyo, Japan.

Allen G.R., Erdmann M.V. 2012. Reef fishes of the East Indies. Vol. 3. Tropical Reef Research, Perth, WA, Australia.

Cantor T. 1849. Catalog of Malayan fishes. Journal of the Asiatic Society of Bengal 18 (2): 983-1443.

Hoese D.F., Shibukawa K., Johnson J.W. 2016. Description of a new species of Tomiyamichthys from Australia with a discussion of the generic name. Zootaxa 4079 (5): 582-594.

DOI: $10.11646 /$ zootaxa.4079.5.5

Kuiter R.W., Tonozuka T. 2001. Pictorial guide to Indonesian reef fishes. Part 3. Jawfishes-SunfishesOpistognathidae-Molidae. Zoonetics, Seaford, VIC, Australia.

Miller P.J. 1986. Gobiidae. Pp. 1019-1085. In: Whitehead P.J.P., Bauchot M.-L., Hureau J.-C., Nielsen J., Tortonese E. (eds.) Fishes of the North-eastern Atlantic and the Mediterranean. Vol. 3. UNESCO, Paris.

Rajan P.T., Vikas N. 2015. Gobiid fishes (Perciformes: Gobiidae) of the Andaman and Nicobar Islands: New records. Pp.113-121. In: National Seminar on Harmonizing Biodiversity and Climate Change: Challenges and Opportunity (NSBC-2015), April 1719, 2015, ICAR-Central Island Agricultural Research Institute, Port Blair, Andaman and Nicobar Islands, India.

Senou H., Suzuki T., Shibukawa K., Yano K. 2004. [A photographic guide to the gobioid fishes of Japan.] Heibonsha Publishers, Tokyo, Japan. [In Japanese.]

Shibukawa K., Suzuki T., Senou H., Yano K. 2005. Records of three shrimp-goby species (Teleostei, Perciformes, Gobiidae) from the Ryukyu Archipelago, Japan. Bulletin of the National Science Museum Tokyo, Series A, Zoology 31 (4): 191-204.

Smith J.L.B. 1956. [LCVII.] An interesting new gobioid fish from Madagascar, with a note on Cryptocentrus oni Tomiyama, 1936. Annals and Magazine of Natural History Series 129 (104): 54-57. DOI: $10.1080 / 00222935608655856$

Received: 17 April 2017 Accepted: 23 September 2017 Published electronically: 31 December 2017 